Article

\title{
Do Controlling Shareholders Who Pledged Their Shares Affect Sustainable Development? An Investigation Based on the Perspective of Corporate Innovation
}

\author{
Caiyue Ouyang ${ }^{1}{ }^{\mathbb{D}}$, Xin Wang ${ }^{2, *}$ and Jiacai Xiong ${ }^{3, *}$ \\ 1 School of Economics and Management, Beijing Jiaotong University, Beijing 100089 China; \\ caiyueouyang@bjtu.edu.cn \\ 2 School of Business, Renmin University of China, Beijing 100089, China \\ 3 School of Accounting, Jiangxi University of Finance and Economics, Nanchang 330013, China \\ * Correspondence: 2016000812@ruc.edu.cn (X.W.); xiongjiacai@jxufe.edu.cn (J.X.)
}

Received: 18 April 2019; Accepted: 8 May 2019; Published: 14 May 2019

\begin{abstract}
We examine the impact of share pledging (SP) on a firm's innovation using a sample of Chinese firms. Our findings show that when controlling shareholders pledged their shares in personal loans, their firm's innovation decreases. Our findings are robust for alternative metrics of innovation and SP. Additional analyses suggest that when controlling shareholders have little ownership or stock price volatility is high, the impact of SP on corporate innovation magnifies, presumably due to the high margin call risk of share against the pledged controlling shareholders. Overall, our study shows that the self-interest of controlling shareholders with pledged shares impedes corporate innovation, thereby impeding the sustainable development of society.
\end{abstract}

Keywords: share pledging; corporate innovation; self-interest; sustainable development

\section{Introduction}

Share pledging (SP) refers to a scenario in which one or more controlling shareholders use their shares as collateral in their personal loans. Since the loans are at the personal level, they do not affect the capital structure of the firm, and thus, in principle, it should not have any impact on the firm and sustainable development of a country. However, in practice, pledged shares are subject to margin calls if the value of pledged shares plummets. Controlling shareholders will post additional margin and/or lose controlling rights of the firm, when the stock price meets the margin call. As a result, they are likely to place pressure on managers to boost the stock price and/or minimize decreases in the stock price for self-interest. Hence, SP affects the incentives of controlling shareholders, and ultimately, changes some policies of the SP firm (i.e., a firm, in which controlling shareholders have already pledged their shares). Specifically, share pledged shareholders conduct unethical behavior for self-interest at the expense of minority shareholders, which finally hurts firm value. Furthermore, some of these unethical behaviors hinder firms to engage in activities, which can bring long-run benefits to firms and society, thereby impeding the sustainable development of a country.

The SP literature has shown that the concerns regarding controlling shareholders' unethical behavior are valid. For instance, Asija et al. [1] and Xie and Liao [2] document that SP firms engage in more accrual-based and real earnings management to cover up operating weakness to minimize stock price decreases. Chan et al. [3] report that SP firms conduct more stock repurchases to boost stock prices than those of non-SP firms. Similarly, Ouyang et al. [4] find that SP lowers the executive pay-for-performance sensitivity relative to a non-SP firm. These activities are non-optimal because 
SP firms that conduct them with an eye for controlling shareholders' own interests rather than for enhancing the value of the firm. Thus, these opportunistic activities destroy firm value. While it is clear that SP firms engage in earnings management or stock repurchases to protect controlling shareholders' self-interest, it is not straightforward to determine the reaction of SP firms to corporate innovation that is critical to the sustainable development of firms and a country.

According to the Oslo Manual's definition, innovation is a new or improved production or process (or combination thereof) that differs significantly from the unit's previous products or process and that has been made available to potential uses (product) or brought into use by the unit (process) (OECD and Eurostat [5]). Innovative firms differ their products/services from their competitors' and make them more attractive to customers, which significantly increase corporate value (Balsmeier et al. [6]). Therefore, we expect that controlling shareholders are interested in spending resources to enhance corporate innovation because successful corporate innovation can boost stock price in the long-term. However, the innovation activity typically requires a long cycle and is risky in nature (Holmstrom [7]). Controlling shareholders may not have time to focus on the long term, and thus require the firm to cut innovation expenses to save resources for other stock price-boosting activities. Few studies explore the impact of SP on innovation. Hence, it is not clear whether SP encourages or impedes corporate innovation.

In addition, our study is also motivated by the fact that innovation plays an important role in sustainable development of a country (Choi and Han [8]; Krozer and Nentjes [9]; Silvestre and Tirca [10]). The world economy has grown rapidly over the past decades, while pollution and climate change problems have become more severe than ever before. Especially in developing countries, such as China, fast economic growth causes serious environmental problems, impeding the sustainable development of the country. However, innovation can improve energy efficiency, reduce pollutant emissions, and bring many other social and environmental benefits, contributing to the sustainable development of the society (Fisher-Vanden et al. [11]; Jin et al. [12]; Tang et al. [13]). Therefore, governments and intergovernmental organizations around the world recognize the key role of innovation in addressing social and global challenges, including demographic shifts, disease threats, resource scarcity, climate change, and supporting higher living standards (OECD and Eurostat [5]).

We argue that firms engaging in innovation activities can significantly contribute to the sustainable development of a country. The reasons are as follows. First, firms consume energy, emit major pollutants, and do many other harmful activities to the environment in the production process. For example, Griffin [14] finds that just 100 companies have been the source of more than $70 \%$ of the world's greenhouse gas emissions since 1988. Hence, firms that engage in innovation activities can greatly reduce energy consumption and pollutants emission. Second, firms are the major units of the economic activity in a country and the main force of innovation. Actually, corporate innovation makes the major contributions to the economic growth and sustainable development of a country (Baumol [15]; OECD and Eurostat [5]). Hence, from a sustainable development perspective, it is also interesting to study how SP impacts corporate innovation. Our findings can guide a country's sustainable development strategy in setting SP regulations.

The objective of this paper is to examine the impact of SP on corporate innovation using a sample of Chinese firms. The Chinese environment is suitable for our investigation for two reasons. First, similar to other financial markets, China allows controlling shareholders to conduct SP. According to our summary statistics, SP is popular in China. Approximately 35\% of Chinese firms have SP, while only $19 \%$ of US firms and 33\% of Taiwanese firms have SP (Chan et al. [3]). Thus, it is informative to examine our research question by using Chinese firms, and the Chinese findings are applicable in other markets. Second, although the last 30 years have witnessed the economic miracle of China, its traditional extensive growth model based on high energy consumption and high pollution is unsustainable and has caused serious environmental problems. Innovation plays an important role in reducing environment pollutions and promoting sustainable development (Choi and Han [8]; Krozer and Nentjes [9]; Silvestre and Tirca [10]; OECD and Eurostat [5]). The Chinese government recognizes 
the importance of innovation and promulgates varieties of policies to encourage innovation. The 13th Five-Year Plan (2016-2020) released in March 2016 chose innovation-led development as the key principle to tackle energy and climate problems and to achieve sustainable growth. The Chinese government also allows firms to deduct $175 \%$ of research and development investments from taxable income as an expense. The tax policy, in part, plays a role in propelling corporate innovation in China. According to the China's official statistics, Chinese firms' aggregated research and development investments to GDP ratio grew from 1.40 percent in 2007 to 2.12 percent in 2016, which is very close to the OECD average. While the government policy promotes corporate innovation and some studies suggest political stability and access to private debt contribute to innovation (Cumming et al. [16]), little is known about how other underlying firm-level factors affect innovation, which furthermore is beneficial for sustainable development. Therefore, the findings regarding the impact of SP on innovation provide guidance on sustainable strategy in terms of identifying the underlying drivers of corporate innovation in an emerging economy. Other emerging markets which undergo sustainable development problems can learn from the Chinese lessons.

Our paper makes two major contributions. First, we document the adverse impact of SP on a firm's sustainable development in the lens of innovation. While conceptually it is not clear whether $\mathrm{SP}$ encourages or discourages innovation, the robust evidence suggests the latter. Our findings are consistent with the literature that SP changes the behavior of controlling shareholders and makes them less ethical, which negatively affects firm value and sustainable development.

Second, our findings show that SP impedes corporate innovation and hurts sustainable development of a country. Despite the adverse impact of SP, the regulations on SP are surprisingly minimal. For instance, with the exception of the UK, the major financial markets in the US, Australia, and Hong Kong do not specifically ask for disclosure of SP by controlling shareholders within one day (Hwang et al. [17] (p. 50)). In fact, China even deregulated SP in 2013 by adopting a new regulation ("Notice on the Issuing the Measures for Stock Pledged Repo Transactions and Registration and Settlement") to easily allow controlling shareholders to pledge stock. It appears that national governments, especially those of emerging markets, do not realize the potential adverse impact of SP on their countries' sustainable development through reducing firms' innovation. Our findings suggest that the 2013 Chinese law may not be a great regulatory reform. Given the importance of corporate innovation in promoting a county's sustainable development, our Chinese evidence implies that it may be in the best interest of a country to review its regulations on SP.

The remaining sections of this paper are as follows. Section 2 contains the background, literature review and hypothesis development. Section 3 presents the methods and data description. Section 4 presents the empirical results and discussion. In the last section, we describe the conclusions of this paper.

\section{Background, Literature Review and Hypothesis Development}

$\mathrm{SP}$ is a global phenomenon. Both developed and emerging markets allow controlling shareholders to conduct SP (Hwang et al. [17]). Ouyang et al. [4] attribute the popularity of SP to the fact that controlling shareholders can obtain funds from their pledged shares, while maintaining their ownership of the firm. That is, controlling shareholders have liquidity after SP, but at the same time, they can participate in the upside benefits of being shareholders of their firms. Most importantly, the lenders (e.g., banks) have liquid collateral when making the loans. The lending relationship, however, hinges on the value of the pledged shares. If share price drops, lenders naturally ask the controlling shareholders to post additional margin (Chan et al. [3]). When controlling shareholders are unable to meet margin calls, lenders sell the pledged shares in the market, resulting in a change of ownership of the firm. It is the risk of margin calls and loss of ownership that changes the behavior of controlling shareholders, which generally leads to adverse impacts on a firm that destroys firm value (Asija et al. [1]; Chan et al. [3]; Ouyang et al. [4]). 
The findings in several recent studies of SP, such as Asija et al. [1], Xie and Liao [2], Chan et al. [3], and Ouyang et al. [4], illustrate that SP firms may engage in some unethical behaviors. Specifically, when compared to non-SP firms, SP firms have more severe accrual-based and real earnings management (Asija et al. [1]; Xie and Liao [2]), more stock repurchase (Chan, et al., [3]), and a decrease in executive-pay-for performance sensitivity (Ouyang et al. [4]). The reason that SP firms engage in earnings management, non-optimal payout policy and lower executive-pay-for performance sensitivity is to help the controlling shareholders avoid margin call risk, which disturbs the resource allocation efficiency and destroy firm value. Obviously, all these behaviors are unethical, which may lead to less innovation (Riivari and Lämsä [18]). In a parallel body of literature, several studies document that SP raises the risk of a firm. For instance, using a sample of Taiwanese banks, Chen and Kao [19] document that the stock price volatility of SP banks is higher than those of non-SP banks. Dou et al. [20] report a negative market reaction to SP announcements for firms. Using the adoption of a company law that protects minority shareholders, Wang and Chou [21] report a positive market reaction for a sample of Taiwanese SP firms. In the context of the bond market default spread, Ouyang et al. [22] show that the bond default risk premium increases after a firm discloses SP. Overall, this body of literature concludes that SP raises the risk of a firm due to the changed behavior of controlling shareholders after an SP.

As the essential drivers of a country's economic growth and sustainable development, innovation has attracted great attention from academic research. Researchers have explored wide determinants of innovation from country-, market- and firm-perspective. Brown et al. [23] find that strong shareholder protection and better access to the stock market have a positive impact on innovation investments. Fang et al. [24] find that intellectual property rights protection is beneficial to firms' innovative incentives. Aghion et al. [25] find an inverted-U relationship between product market competition and innovation. Balsmeier et al. [6] show that firms that transition to independent boards focus on more crowded and familiar areas of technology. He and Tian [26] suggest that analysts exert too much pressure on managers to meet short-term goals, impeding firms' investment in long-term innovative projects. Jiang and Yuan [27] find that institutional investors' site visits significantly enhance corporate innovation. However, little is known about the effect of stock pledge.

We argue that the ultimate goal of controlling shareholders in an SP firm is to boost the stock price or minimize the decrease of the stock price to protect themselves against margin call risk and/or losing ownership control. Some corporate activities, such as corporate innovation, may work both ways. First, successful corporate innovation enhances a firm's future and boosts its stock price in the long-term. For instance, innovation, in terms of research and development investments, plays a critical role in the success of a firm's initial public offerings (Guo and Zhou [28]) and operating and stock price performance (Chan et al. [29]; Eberhart et al. [30]) over the long term. Thus, it may be in the best interests of controlling shareholders to increase innovation to boost the stock price in the long term.

Second, innovation activities have risk. They may or may not succeed in getting tangible results to enhance a firm's future (Holmstrom [7]). In some cases, a firm may choose cutting research and development investments to boost short-term performance (Zhou et al. [31]). In the context of SP, controlling shareholders may be short-sighted and opt for cutting research and development investments. Thus, innovation in the future is reduced. Hence, our core testable hypothesis is:

Hypothesis 1 (H1). SP affects firm innovation, but the direction is unclear. 


\section{Methods and Data}

\subsection{Methodology and Variable Construction}

To assess how share pledge affects innovation, we follow the literature on innovation (e.g., He and Tian [26]; Balsmeier et al. [6]; Jiang and Yuan [27]) and estimate the baseline multivariate regression model using Ordinary Least Square (OLS):

$$
\begin{gathered}
\text { INNOVATION }_{i, t+1}=\alpha_{0}+\alpha_{1}^{*} \text { PLEDGE_DUM } \\
+ \text { CONTROL }+ \text { INDUSTRY }+ \text { YEAR }+\varepsilon_{i, t}
\end{gathered}
$$

Where INNOVATION is the corporate innovation. While some studies use research and development investment (Zang et al. [32]), we follow Tong et al. [33] and Jiang and Yuan [27], we use the logarithm value of 1 plus the total number of all patents filed (LNPATENT), the logarithm value of 1 plus total number of invention patents filed (LNINVENT), and the logarithm value of 1 plus total number of invention patents granted (LNGRANT) in year $t+1$ to capture the reaction of corporate innovation to SP in year $t$. In addition to LNPATENT, LNINVENT, and LNGRANT, we also use the logarithm value of 1 plus total number of different international patent classifications (IPC) on invention patent in year $t+1$ (LNIPC) and research and development expense per total assets $(R D)$ in year $t$ in our robustness checks. LNIPC accounts for the patent applications of a different variety of inventions to reflect the breath of innovation, while $R D$ captures the innovation input of a firm. For SP in year $t$, we use a dummy variable with a value of 1 if the firm has one or more controlling shareholders who have pledged their shares in year $t$ (PLEDGE_DUM) and the proportion of shares pledged (PLEDGE_RATIO) in a firm following Chan et al. [3] and Ouyang et al. [4].

Following the innovation literature (e.g., Atanassov [34]; He and Tian [26]; Balsmeier et al. [6]; Jiang and Yuan [27]), we control for a vector of firm characteristics that could confound the relationship between share pledge and a firm's innovation. Hall and Ziedonis [35], for example, argue that the number of patent applications is positively related to firm size. Therefore, we control for firm size (SIZE), measured by the natural logarithm of total asset. We also control for firm leverage ( $L E V$, the sum of short-terms borrowing plus the long-term debts divided by total assets), cash flow from operations (CASHFLOW) and capital expenditure (INV) to account for financial constraints that are known to influence corporate innovation. As an older firm may search in older technological areas, we control for firm age $(A G E)$. Tobin's $Q(Q)$ enters the regression to control for differences in growth opportunities. Additionally, the following variables are considered: Profitability measured by return on assets $(R O A)$ and asset tangibility measured by the ratio of tangible assets divided by firm assets (PPE). Variable definitions are presented in Appendix A, Table A1. We also control for industry and year fixed effects.

\subsection{Data}

Our initial sample includes all China's A-share listed firms covered by the China Stock Market and Accounting Research (CSMAR) database for the period of 2003-2016. Since SP information for all China A-share firms is unavailable in CSMAR before 2003, we choose 2003 as the beginning of the research period. We obtain other financial data from CSMAR. We start with a sample of 28,311 firm-year observations from 2003-2016. We then exclude (i) 469 firm-years in the financial industry; (ii) 3050 firm-years with missing value in patent; (iii) 1084 firm-years whose data on SP or control variables are unavailable. Finally, we obtain 23,708 firm-years. Furthermore, we winsorize the data at the $1 \%$ and $99 \%$ levels to mitigate the influence of outliers. 


\section{Results and Discussions}

\subsection{Descriptive Statistics and Univariate Analysis}

We report the descriptive statistics of all variables in Panel A of Table 1. The means of LNPATENT, LNINVENT, and LNGRANT are 1.701, 1.145, and 0.932, respectively. The mean of PLEDGE_DUM and PLEDGE_RATIO is 0.353 and 0.218 , respectively, indicating that there are approximately $35.3 \%$ of firms with SP, and the mean SP ratio is $21.8 \%$, which is consistent with Ouyang et al. [4]. Thus, similar to other countries, SP by controlling shareholders in China is common.

Table 1. Descriptive statistics and univariate analysis.

\begin{tabular}{|c|c|c|c|c|c|c|}
\hline \multicolumn{7}{|c|}{ Panel A: Descriptive statistics } \\
\hline Variable & $\mathbf{N}$ & Mean & Std & Median & Min & Max \\
\hline LNPATENT $_{i, t+1}$ & 23,708 & 1.701 & 1.711 & 1.386 & 0 & 6.087 \\
\hline LNINVENT $_{i, t+1}$ & 23,708 & 1.145 & 1.381 & 0.693 & 0 & 5.182 \\
\hline$L_{N G R A N T}$ & 23,708 & 0.932 & 1.237 & 0 & 0 & 4.748 \\
\hline$L_{N N P C_{i, t+1}}$ & 23,708 & 1.272 & 1.494 & 0.693 & 0 & 5.187 \\
\hline$R D_{i, t}$ & 22,672 & 0.012 & 0.016 & 0.004 & 0 & 0.083 \\
\hline PLEDGE_DUM $M_{i, t}$ & 23,708 & 0.353 & 0.478 & 0 & 0 & 1 \\
\hline PLEDGE_RATIO ${ }_{i, t}$ & 23,708 & 0.218 & 0.354 & 0 & 0 & 1 \\
\hline$H H I 5_{i, t}$ & 23,707 & 0.180 & 0.127 & 0.150 & 0 & 0.810 \\
\hline$S I G M A_{i, t}$ & 23,541 & 0.031 & 0.010 & 0.029 & 0.013 & 0.064 \\
\hline$R P T_{i, t}$ & 22,146 & 0.046 & 0.122 & 0 & 0 & 0.745 \\
\hline ORECTA $_{i, t}$ & 23,708 & 0.030 & 0.059 & 0.010 & 0 & 0.440 \\
\hline$S I Z E_{i, t}$ & 23,708 & 21.68 & 1.247 & 21.53 & 18.96 & 25.66 \\
\hline$L E V_{i, t}$ & 23,708 & 0.462 & 0.207 & 0.469 & 0.113 & 0.821 \\
\hline CASHFLOW $_{i, t}$ & 23,708 & 0.043 & 0.079 & 0.043 & -0.211 & 0.267 \\
\hline$A G E_{i, t}$ & 23,708 & 9.514 & 5.814 & 9 & 0 & 24 \\
\hline$P P E_{i, t}$ & 23,708 & 0.255 & 0.179 & 0.221 & 0.002 & 0.754 \\
\hline$I N V_{i, t}$ & 23,708 & 0.058 & 0.056 & 0.041 & 0 & 0.271 \\
\hline$R O A_{i, t}$ & 23,708 & 0.032 & 0.067 & 0.034 & -0.320 & 0.204 \\
\hline$Q_{i, t}$ & 23,708 & 2.443 & 1.478 & 1.917 & 1.048 & 6.567 \\
\hline \multicolumn{7}{|c|}{ Panel B: Univariate analysis } \\
\hline & \multicolumn{2}{|c|}{$P$ LEDGE_DUM $=0$} & \multicolumn{2}{|c|}{$P$ LEDGE_DUM $=1$} & Mean Test & Median Test \\
\hline & Mean & Median & Mean & Median & & \\
\hline LNPATENT $_{i, t+1}$ & 1.755 & 1.609 & 1.603 & 1.386 & $0.152^{* * *}$ & $28.626^{* * *}$ \\
\hline $\operatorname{LNINVENT}_{i, t+1}$ & 1.184 & 0.693 & 1.075 & 0.693 & $0.109^{* * *}$ & $13.296^{* * *}$ \\
\hline $\operatorname{LNGRANT}_{i, t+1}$ & 0.965 & 0.000 & 0.872 & 0.000 & $0.094^{* * *}$ & $7.148^{* * *}$ \\
\hline$L_{N N P C} C_{i, t+1}$ & 1.414 & 1.099 & 1.321 & 0.693 & $0.094^{* * *}$ & $8.000^{* * *}$ \\
\hline$R D_{i, t}$ & 0.012 & 0.004 & 0.011 & 0.003 & $0.091^{* * *}$ & $9.677^{* * *}$ \\
\hline
\end{tabular}

Panel A of Table 1 presents descriptive statistics of the sample. Panel B of Table 1 presents the results for the univariate tests of the subsample of firms with and without share pledging. The definitions of the variables are presented in Table A1. ${ }^{* * *},{ }^{* *}$, and ${ }^{*}$ indicate $1 \%, 5 \%$, and $10 \%$ significance, respectively.

In Panel B of Table 1, we present the results of the univariate analysis on various innovation variables based on subsamples of firms with $\left(P L E D G E_{-} D U M=1\right)$ and without SP $\left(P L E D G E \_D U M=0\right)$. Consistently across all five innovation measures (LNPATENT, LNINVENT, LNGRANT, LNIPC, and $R D)$, the mean and medians for the non-SP firms are larger than those of SP firms. The findings are significant at the $1 \%$ level. Hence, the preliminary findings suggest that SP firms have less innovation than non-SP firms. 


\subsection{Core Findings}

We present the results for Equation (1) in Table 2. Across six columns, the coefficients of PLEDGE_DUM and PLEDGE_RATIO are consistently negative and significant at the $5 \%$ level, suggesting that when a firm's controlling shareholder pledged their shares, the firm has less innovation. While the SP literature (Asija et al. [1]; Xie and Liao [2]; Chan et al. [3]) suggests that a controlling shareholder protects one's own self-interest by engaging in opportunistic activities, it is not clear, conceptually, how self-interest drives innovation. In our case, SP firms decrease innovation relative to non-SP firms, suggesting a controlling shareholder's short-termism in boosting the stock price outweighs the long-term benefits boosting the stock price due to innovation. The results are robust with respect to different innovation metrics. Hence, our findings support the hypothesis that a controlling shareholder takes the short-term approach to save funds for innovation in order to use the funds elsewhere in boosting the stock price.

Table 2. Share pledging and corporate innovation.

\begin{tabular}{|c|c|c|c|c|c|c|}
\hline & \multicolumn{2}{|c|}{ LNPATENT $_{i, t+1}$} & \multicolumn{2}{|c|}{ LNINVENT $_{i, t+1}$} & \multicolumn{2}{|c|}{ LNGRANT $_{i, t+1}$} \\
\hline & (1) & (2) & (3) & (4) & (5) & (6) \\
\hline PLEDGE_DUM $M_{i, t}$ & $\begin{array}{c}-0.086^{* *} \\
(0.034)\end{array}$ & & $\begin{array}{c}-0.068 \text { ** } \\
(0.028)\end{array}$ & & $\begin{array}{c}-0.061 \text { ** } \\
(0.026)\end{array}$ & \\
\hline PLEDGE_RATIO ${ }_{i, t}$ & & $\begin{array}{c}-0.110 * * \\
(0.046)\end{array}$ & & $\begin{array}{c}-0.090 * * \\
(0.038)\end{array}$ & & $\begin{array}{c}-0.080 \text { ** } \\
(0.034)\end{array}$ \\
\hline$S I Z E_{i, t}$ & $\begin{array}{c}0.480 * * * \\
(0.026)\end{array}$ & $\begin{array}{c}0.479^{* * *} \\
(0.026)\end{array}$ & $\begin{array}{c}0.433 * * * \\
(0.023)\end{array}$ & $\begin{array}{c}0.431^{* * *} \\
(0.024)\end{array}$ & $\begin{array}{c}0.392 * * * \\
(0.022)\end{array}$ & $\begin{array}{c}0.391 * * * \\
(0.022)\end{array}$ \\
\hline$L E V_{i, t}$ & $\begin{array}{c}-0.320 * * * \\
(0.104)\end{array}$ & $\begin{array}{c}-0.322 * * * \\
(0.104)\end{array}$ & $\begin{array}{c}-0.251^{* * *} \\
(0.087)\end{array}$ & $\begin{array}{c}-0.253^{* * *} \\
(0.087)\end{array}$ & $\begin{array}{c}-0.221 * * * \\
(0.077)\end{array}$ & $\begin{array}{c}-0.222 * * * \\
(0.077)\end{array}$ \\
\hline CASHFLOW $_{i, t}$ & $\begin{array}{c}0.550 * * * \\
(0.150)\end{array}$ & $\begin{array}{c}0.554^{* * *} \\
(0.150)\end{array}$ & $\begin{array}{c}0.466^{* * *} \\
(0.124)\end{array}$ & $\begin{array}{c}0.468^{* * *} \\
(0.124)\end{array}$ & $\begin{array}{c}0.466^{* * *} \\
(0.111)\end{array}$ & $\begin{array}{c}0.468^{* * *} \\
(0.111)\end{array}$ \\
\hline$A G E_{i, t}$ & $\begin{array}{c}-0.025^{* * *} \\
(0.004)\end{array}$ & $\begin{array}{c}-0.025^{* * *} \\
(0.004)\end{array}$ & $\begin{array}{c}-0.018^{* * *} \\
(0.003)\end{array}$ & $\begin{array}{c}-0.017^{* * *} \\
(0.003)\end{array}$ & $\begin{array}{c}-0.015^{* * *} \\
(0.003)\end{array}$ & $\begin{array}{c}-0.015^{* * *} \\
(0.003)\end{array}$ \\
\hline$P P E_{i, t}$ & $\begin{array}{c}-0.839 * * * \\
(0.131)\end{array}$ & $\begin{array}{c}-0.842^{* * *} \\
(0.131)\end{array}$ & $\begin{array}{c}-0.629 * * * \\
(0.107)\end{array}$ & $\begin{array}{c}-0.632^{* * *} \\
(0.107)\end{array}$ & $\begin{array}{c}-0.542 \text { *** } \\
(0.095)\end{array}$ & $\begin{array}{c}-0.545^{* * *} \\
(0.096)\end{array}$ \\
\hline$I N V_{i, t}$ & $\begin{array}{c}0.317 \\
(0.245)\end{array}$ & $\begin{array}{c}0.306 \\
(0.245)\end{array}$ & $\begin{array}{l}0.373^{*} \\
(0.210)\end{array}$ & $\begin{array}{l}0.363 \text { * } \\
(0.210)\end{array}$ & $\begin{array}{c}0.300 \\
(0.191)\end{array}$ & $\begin{array}{c}0.292 \\
(0.191)\end{array}$ \\
\hline$R O A_{i, t}$ & $\begin{array}{c}1.323^{* * *} \\
(0.215)\end{array}$ & $\begin{array}{c}1.302^{* * *} \\
(0.216)\end{array}$ & $\begin{array}{c}0.708^{* * *} \\
(0.179)\end{array}$ & $\begin{array}{c}0.690^{* * *} \\
(0.179)\end{array}$ & $\begin{array}{c}0.566^{* * *} \\
(0.160)\end{array}$ & $\begin{array}{c}0.549^{* * * *} \\
(0.161)\end{array}$ \\
\hline$Q_{i, t}$ & $\begin{array}{c}0.044^{* * *} \\
(0.015)\end{array}$ & $\begin{array}{c}0.044^{* * *} \\
(0.015)\end{array}$ & $\begin{array}{c}0.078^{* * *} \\
(0.012)\end{array}$ & $\begin{array}{c}0.078^{* * *} \\
(0.012)\end{array}$ & $\begin{array}{c}0.074^{* * *} \\
(0.011)\end{array}$ & $\begin{array}{c}0.074^{* * *} \\
(0.011)\end{array}$ \\
\hline Constant & $\begin{array}{c}-8.779 * * * \\
(0.531)\end{array}$ & $\begin{array}{c}-8.751^{* * *} \\
(0.533)\end{array}$ & $\begin{array}{c}-8.583^{* * *} \\
(0.483)\end{array}$ & $\begin{array}{c}-8.559 * * * \\
(0.485)\end{array}$ & $\begin{array}{c}-7.663 \text { *** } \\
(0.451)\end{array}$ & $\begin{array}{c}-7.642 * * * \\
(0.452)\end{array}$ \\
\hline Year and industry & Yes & Yes & Yes & Yes & Yes & Yes \\
\hline$N$ & 23,708 & 23,708 & 23,708 & 23,708 & 23,708 & 23,708 \\
\hline Adjusted $R^{2}$ & 0.448 & 0.448 & 0.383 & 0.383 & 0.353 & 0.353 \\
\hline$F$ & 130.9 & 128.45 & 85.78 & 84.33 & 83.21 & 81.94 \\
\hline
\end{tabular}

Table 2 reports the impact of share pledging on corporate innovation. All models include year and industry fixed effects. Robust standard errors that are clustered by firm are presented in parentheses. Definitions are presented in Table A1. ${ }^{* *},{ }^{* *}$, and ${ }^{*}$ denote significance at the $1 \%, 5 \%$, and $10 \%$ levels, respectively.

The findings in Table 2 are economically significant. For instance, the coefficient of PLEDGE_RATIO is -0.110 in column (2). A one standard deviation increase in PLEDGE_RATIO (0.354 in Panel A of Table 1) leads to a $3.89 \%$ decrease in the number of patents filed in one year.

The control variables, if significant, carry the expected signs. For instance, the coefficients of SIZE, CASHFLOW, ROA, and $Q$ are all positive and significant at the $1 \%$ level, which are consistent with the intuition that when a firm is bigger (SIZE or $Q$ is large), the firm is more profitable (ROA is high), or the firm has sufficient cash resource (CASHFLOW is high), or the firm conducts more innovation. The above results are consistent with the finding of He and Tian [18]. In contrast, the coefficients of $L E V, A G E$, and PPE, are consistently negative and significant at the $1 \%$ level, which are consistent with 
Atanassov [34] and Jiang and Yuan [27]). Hence, when a firm has high financial leverage, is older, or has a large quantity of fixed investment, it either does not have sufficient resources to conduct innovation or the incentive to do so is lower.

\subsection{Robustness Checks}

We conduct several robustness checks on our core findings in Section 3.2. The findings are presented in Panels A to E of Table 3. For brevity, we do not present the coefficients for control variables. First, we present the findings using the LNIPC in year $t+1$ and $R D$ in year $t$ as our dependent variables in Equation (1) in Panel A. These two variables capture different aspects of a firm's innovation in terms of the different variety of invention patent applications (LNIPC) or innovation input $(R D)$. The coefficients of PLEDGE_DUM and PLEDGE_RATIO continue to be negative and significant at the $1 \%$ or $5 \%$ level, suggesting the adverse impact of SP on innovation is robust to different metrics of innovation.

Table 3. The impact of shares pledging on corporate innovation: Robust analyses.

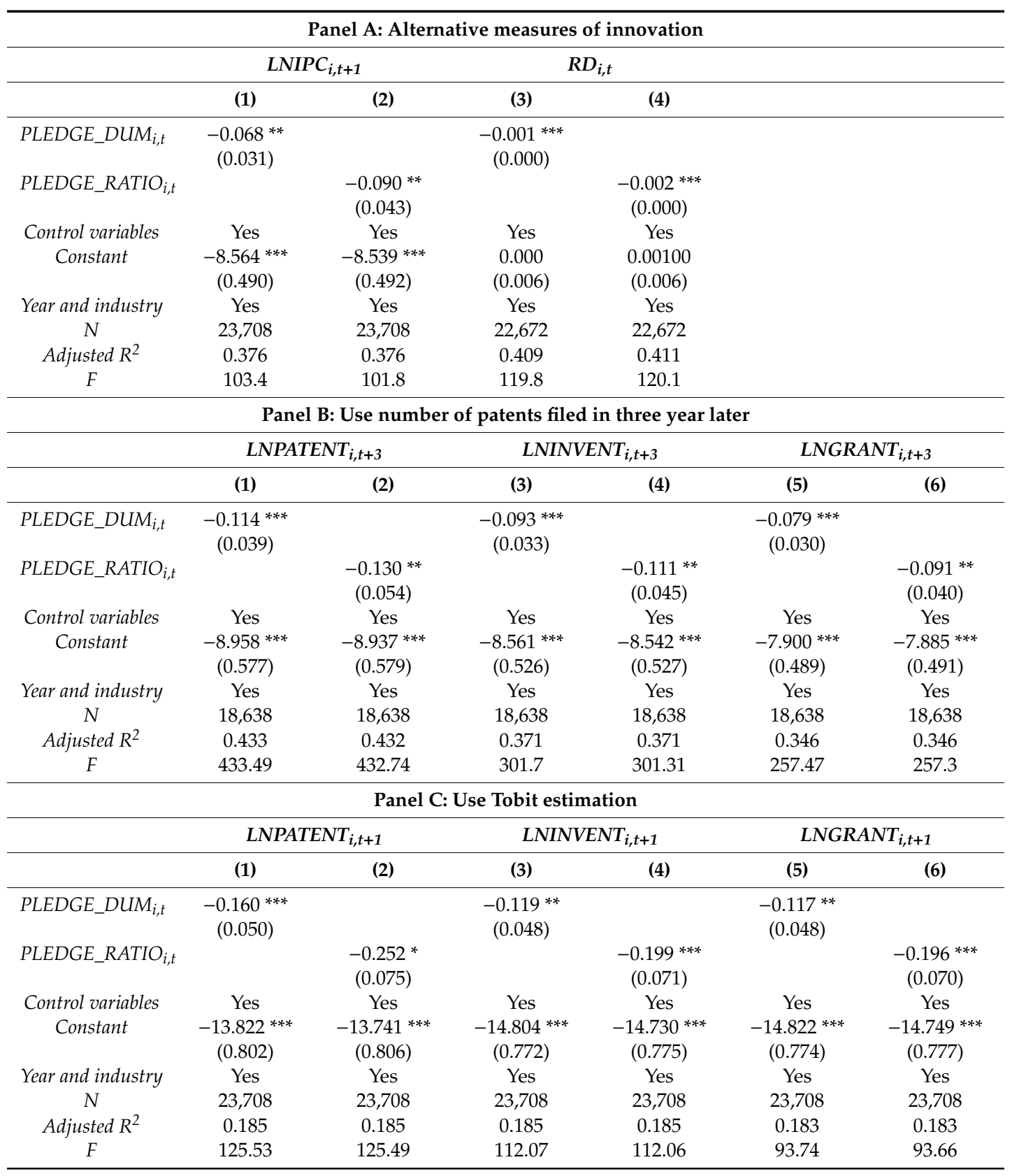


Table 3. The impact of shares pledging on corporate innovation: Robust analyses.

\begin{tabular}{|c|c|c|c|c|c|c|}
\hline \multicolumn{7}{|c|}{ Panel D: Propensity score matching } \\
\hline & \multicolumn{2}{|c|}{ LNPATENT $_{i, t+1}$} & \multicolumn{2}{|c|}{ LNINVENT $_{i, t+1}$} & \multicolumn{2}{|c|}{ LNGRANT $_{i, t+1}$} \\
\hline & (1) & (2) & (3) & (4) & (5) & (6) \\
\hline PLEDGE_DUM $M_{i, t}$ & $\begin{array}{c}-0.0379 * \\
(0.022)\end{array}$ & & $\begin{array}{c}-0.0726^{* *} \\
(0.037)\end{array}$ & & $\begin{array}{c}-0.0695^{* *} \\
(0.034)\end{array}$ & \\
\hline PLEDGE_RATIO ${ }_{i, t}$ & & $\begin{array}{c}-0.0587 * \\
(0.030)\end{array}$ & & $\begin{array}{c}-0.109 * * \\
(0.051)\end{array}$ & & $\begin{array}{c}-0.105^{* *} \\
(0.046)\end{array}$ \\
\hline Control variables & Yes & Yes & Yes & Yes & Yes & Yes \\
\hline Constant & $\begin{array}{c}-9.196^{* * *} \\
(0.464)\end{array}$ & $\begin{array}{c}-9.178^{* * *} \\
(0.464)\end{array}$ & $\begin{array}{c}-9.142^{* * *} \\
(0.600)\end{array}$ & $\begin{array}{c}-9.109 * * * \\
(0.601)\end{array}$ & $\begin{array}{c}-8.250 * * * \\
(0.564)\end{array}$ & $\begin{array}{c}-8.218^{* * *} \\
(0.564)\end{array}$ \\
\hline Year and industry & Yes & Yes & Yes & Yes & Yes & Yes \\
\hline$N$ & 15,403 & 15,403 & 15,403 & 15,403 & 15,403 & 15,403 \\
\hline Adjusted $R^{2}$ & 0.452 & 0.452 & 0.385 & 0.385 & 0.351 & 0.351 \\
\hline F & 382.7 & 382.6 & 261.2 & 260.9 & 215.8 & 215.7 \\
\hline \multicolumn{7}{|c|}{ Panel E: Instrumental variable regression } \\
\hline & \multicolumn{6}{|c|}{ Second Stage } \\
\hline & \multicolumn{2}{|c|}{ LNPATENT $_{i, t+1}$} & \multicolumn{2}{|c|}{ LNINVENT $_{i, t+1}$} & \multicolumn{2}{|c|}{ LNGRANT $_{i, t+1}$} \\
\hline & (3) & (4) & (5) & (6) & (7) & (8) \\
\hline $\begin{array}{c}\text { Predicted } \\
\text { PLEDGE_DUM } \\
\text { i,t }\end{array}$ & $\begin{array}{c}-0.369^{* *} \\
(0.176)\end{array}$ & & $\begin{array}{c}-0.543^{* * *} \\
(0.203)\end{array}$ & & $\begin{array}{c}-0.610 * * * \\
(0.190)\end{array}$ & \\
\hline $\begin{array}{c}\text { Predicted } \\
\text { PLEDGE_RATIO }{ }_{i, t}\end{array}$ & & $\begin{array}{c}-0.956^{* * *} \\
(0.309)\end{array}$ & & $\begin{array}{c}-1.206^{* *} \\
(0.512)\end{array}$ & & $\begin{array}{c}-1.366^{* * *} \\
(0.491)\end{array}$ \\
\hline$A F T E R_{i, t}$ & & & & & & \\
\hline$M \_P L E D G E_{i, t}$ & & & & & & \\
\hline $\begin{array}{l}\text { Control variables } \\
\text { constant }\end{array}$ & $\begin{array}{c}\text { Yes } \\
-8.293^{* * *} \\
(0.283)\end{array}$ & $\begin{array}{c}\text { Yes } \\
-7.618^{* * *} \\
(0.405)\end{array}$ & $\begin{array}{c}\text { Yes } \\
-7.544^{* * *} \\
(0.282)\end{array}$ & $\begin{array}{c}\text { Yes } \\
-6.770 * * * \\
(0.591)\end{array}$ & $\begin{array}{c}\text { Yes } \\
-6.757^{* * *} \\
(0.264)\end{array}$ & $\begin{array}{c}\text { Yes } \\
-5.876^{* * *} \\
(0.567)\end{array}$ \\
\hline Year and industry & Yes & Yes & Yes & Yes & Yes & Yes \\
\hline$N$ & 23,708 & 23,708 & 23,708 & 23,708 & 23,708 & 23,708 \\
\hline Adjusted $R^{2}$ & 0.443 & 0.421 & 0.359 & 0.310 & 0.313 & 0.232 \\
\hline$F$ & 540.5 & 511.9 & 354.9 & 324.6 & 288.9 & 255.1 \\
\hline$K P$ & $220.11^{* * *}$ & $90.40^{* * *}$ & $84.05^{* * *}$ & $46.47^{* * *}$ & $157.12^{* * *}$ & $46.47^{* * *}$ \\
\hline Overid_P & 0.001 & 0.027 & 0.105 & 0.105 & 0.102 & 0.105 \\
\hline
\end{tabular}

Second, due to the long-term nature of innovation, we replace the dependent variable in Equation (1) with the natural logarithm of number of patents filed three years ahead. The results in Panel B show that the coefficients of PLEDGE_DUM and PLEDGE_RATIO are negative and significant at the $1 \%$ or $5 \%$ levels in all six columns. Hence, the adverse impact of SP on corporate innovation occurs in the long term. We also use patents filed in year $t+2$, and the findings are qualitatively similar.

Third, not every firm has corporate innovation. To account for zero corporate innovation in some firms, we estimate Equation (1) again using Tobit model. The findings in Panel $\mathrm{C}$ show that the coefficients of PLEDGE_DUM and PLEDGE_RATIO are negative and significant at the $1 \%, 5 \%$, or $10 \%$ levels in all six columns. Interestingly, the magnitudes of these coefficients are larger than the corresponding coefficients in Table 2. Thus, the adverse impact of SP on innovation is robust to different estimation methods.

Fourth, there is a possibility that SP and innovation are endogenously determined. When a firm has less innovation, its controlling shareholder may then engage in more SP. To mitigate this concern, we use propensity score match (PSM) and instrumental variable regression. For PSM, we have 1493 SP firms (i.e., treatment firms). Using a 1:1 matching with replacement and SIZE, LEV, ROA, AGE, CASHFLOW, industry and year variables as the matching criteria, we have a sample of 1490 treatment and 1116 control firms (we cannot find control firms for three treatment firms), 
with a total of 15,403 firm-year observations. The PSM matched samples alleviate the concern of self-selecting behavior on the part of the controlling shareholder. In Panel D of Table 3, the coefficients of PLEDGE_DUM and PLEDGE_RATIO are negative and significant at the $5 \%$ or $10 \%$ levels in all six columns.

In addition to PSM, we use an instrumental variables approach to mitigate the concern of endogeneity. We use two instruments to predict the PLEDGE_DUM and PLEDGE_RATIO. The first instrument is the industry mean of PLEDGE_RATIO each year excluding the firm $i$ (M_PLEDGE), while the second one is the period in which a new share pledging law was implemented in 2013. In 2013, the Chinese government issued a new law, the "Notice on the Issuing the Measures for Stock Pledged Repo Transactions and Registration and Settlement." The new 2013 law facilitated SP. Hence, we use a dummy variable, AFTER, to capture the impact of the new law starting in 2013 (AFTER has a value of 1 if the year is 2013 or after and zero otherwise). Intuitively, M_PLEDGE and AFTER are highly correlated with SP behavior (PLEDGE_DUM and PLEDGE_RATIO), but they do not directly contribute to corporate innovation activities.

For brevity, we do not present the results for the first stage of the instrumental variables. The results in Panel E of Table 3 show that the coefficients of PREDICTED PLEDGE_DUM and PREDICTED PLEDGE_RATIO in columns (1-6) are consistently negative and significant at the $1 \%$ or $5 \%$ level. The Kleibergen-Paap LM statistics (KP) are all significant at the 1\% level, suggesting that the instruments are valid. In addition, the p-value of Hansen-J statistics (Overid P) do not suggest overidentification.

Hence, from both Panels D and E, the adverse impact of SP on innovation remains intact after accounting for potential endogeneity between SP and innovation.

Panel A of Table 3 reports the impact of share pledging on corporate innovation using alternative measures of innovation. Panel B reports the result using number of patents filed in three year ahead. Panel $C$ reports marginal effect results of Tobit regressions on the impact of share pledging on corporate innovation. Panel D reports ordinary least regressions examining the effect of share pledging on corporate innovation using the sample matched by propensity score matching (PSM). We use SIZE, $L E V, R O A$, firm age, cash flow, industry and year as the main matching criteria. Panel E reports instrumental variable (IV) regressions for the impact of share pledging on firm donation. For brevity, we do not present coefficients of control variables. ${ }^{* * *},{ }^{* *}$, and ${ }^{*}$ denote significance at the $1 \%, 5 \%$, and $10 \%$ levels, respectively. See Table A1 for variable definitions.

\subsection{Micro-Foundation of Testable Hypothesis}

The micro-foundation of our findings depends on controlling shareholders' strong incentives to protect their ownership control and minimize margin call. Following the argument in Ouyang et al. [22], we expect that when the threat of losing control is strong or the margin call risk is high, the impact of SP on innovation is stronger.

To examine our conjecture, we partition the full sample into two subsamples based on controlling shareholders' relative ownership or the volatility of the stock price. Specifically, we use the Herfindahl index of shareholdings of the five largest shareholders (HHI5) and standard deviation of daily returns of the stock in a year (SIGMA). If HHI5 is below its median or SIGMA is above its median each year, then the subsample of firms are subject to high control ownership losing risk or high margin call risk.

We present the findings for the subsamples in Panels A and B of Table 4. For brevity, we do not present the coefficients of control variables and confine our discussion using LNPATENT and LNINVENT (The results are qualitative similar using LNGRANT). In Panel A, the coefficients of PLEDGE_DUM and PLEDGE_RATIO are consistently negative and significant at the $1 \%$ level for the subsamples of low HHI5 in columns $(1,2,5,6)$, while the same coefficients are not significant for the subsamples of high HHI5 in columns $(3,4,7,8)$. Hence, the impact of SP on innovation is more pronounced for firms with controlling shareholders that are marginally more likely to lose ownership control in the case where the lender liquidates pledged shares. The findings are consistent with those in Ouyang et al. [22]. 
Table 4. The risk of losing control rights, shares pledging and corporate innovation.

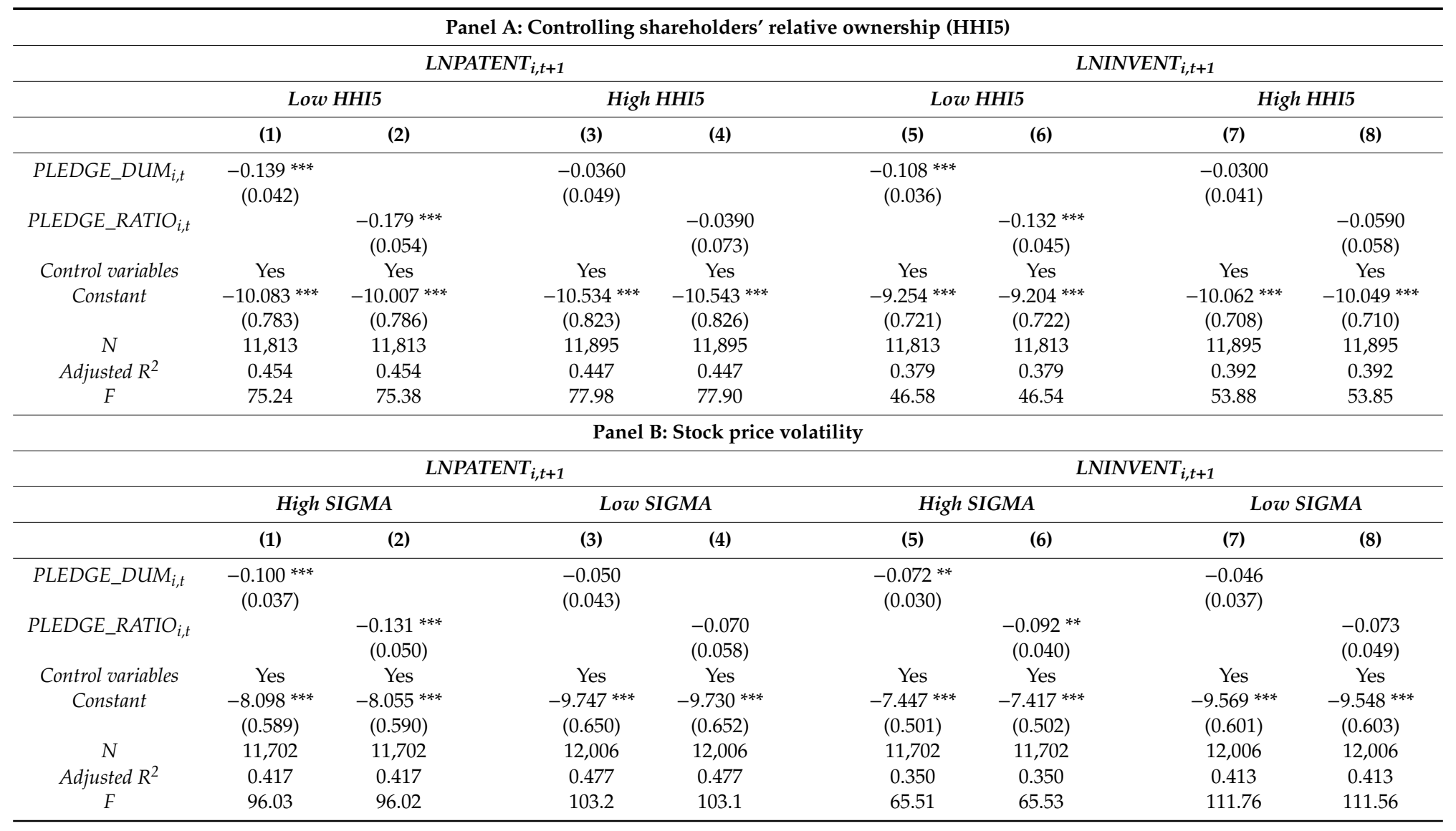


In Panel B of Table 4, the coefficients of PLEDGE_DUM and PLEDGE_RATIO are negative and significant at the $1 \%$ or $5 \%$ level for the high SIGMA subsamples. In contrast, the same coefficients are not significant in the low SIGMA subsamples. The findings in Panel B suggest that when a stock is highly volatile, the decrease in innovation is more pronounced. The results are consistent with our notion that these firms are subject to high margin call risk and that controlling shareholders are more eager to cut innovation to steer the funds elsewhere to boost the stock price. Thus, the findings in Table 4 corroborate the micro-foundation of Hypothesis.

\subsection{Is It Due to Tunneling?}

Previous studies suggest that controlling shareholders have the incentive to expropriate minority shareholders by tunneling the resources of their controlled firms (Tu et al. [36]). Hence, the extent of tunneling by a controlling shareholder may drive innovation. The logic is that if a controlling shareholder tunnels resources out of their controlled firm, that firm certainly has less incentive to innovate. To examine the conjecture, we examine the moderating role of tunneling on the impact of SP on innovation. We use two methods to capture tunneling for robustness.

First, we use related party transaction. Following Jiang et al. [37] and Wang and Xiao [38], we use abnormal related-party transactions and other receivables to measure tunneling by controlling shareholders. Specifically, we run an ordinary least square regression model to remove any normal components of other receivables as follows:

$$
\begin{gathered}
R P T_{i, t}\left(\operatorname{or~ORECTA~}_{i, t}\right)=\beta_{0}+\beta_{1}{ }^{*} R P T_{i, t-1}(\text { or ORECTA } \\
\left.+\beta_{4}{ }^{*} \mathrm{SOE}_{\mathrm{i}, \mathrm{t}}\right)+\beta_{5}{ }^{*} \mathrm{SIZE}_{\mathrm{i}, \mathrm{t}}+\beta_{6}{ }^{*}{ }^{*} \mathrm{LEV}_{\mathrm{i}, \mathrm{t}}+\beta_{7}{ }^{*} \mathrm{MKT}_{\mathrm{i}, \mathrm{t}} \\
+ \\
+ \text { INDUSTRY }+Y E A R+\varepsilon_{i, t}
\end{gathered}
$$

Where $R P T$ is related party transaction, ORECTA is other receivables, SOE is a $(1,0)$ indicator variable with a value of 1 if the firm is state-owned, and $M K T$ is the marketization level of the province in which the firm located. Other variables are defined earlier in Equation (1). We then use residual of Equation (2) as abnormal related-party transactions or abnormal other receivables (the extent of tunneling). If a firm's abnormal related-party transactions or abnormal other receivables is above (below) the median each year, the firm belongs to a high (low) tunneling subsample. The results in Panels A and B of Table 5 show that the coefficients of PLEDGE_DUM and PLEDGE_RATIO are negative and significant in all columns, suggesting that the extent of tunneling does not moderate the impact of SP on innovation. Hence, tunneling does not mediate the impact of SP on innovation.

Table 4 reports the moderating effect of controlling shareholders' relative ownership and volatility of the market. Panel A uses HHI5 as the moderating variable. Low HHI5 is subsample where HHI5 is lower than the industry median each year. Panel B uses stock price volatility. High volatility is subsample where stock price volatility is larger than the industry median each year. For brevity, we do not report the coefficients of control variables. All models include year and industry fixed effects. Robust standard errors that are clustered by firm are presented in parentheses. Definitions of variables are presented in Table A1. ${ }^{* * *}$, **, and ${ }^{*}$ denote significance at the $1 \%, 5 \%$, and $10 \%$ levels, respectively.

Table 5 reports the moderating effect of tunneling on the impact of share pledging on innovation. In Panel A, High RPT is subsample where abnormal related party transactions are larger than the industry median each year. In Panel B, High ORECTA is subsample where abnormal other receivable is larger than the industry median each year. For brevity, we do not report the coefficients of control variables. All models include year and industry fixed effects. Robust standard errors that are clustered by firm are presented in parentheses. Definitions of variables are presented in Table A1. ${ }^{* * *}, * *$, and * denote significance at the $1 \%, 5 \%$, and $10 \%$ levels, respectively. 
Table 5. Is it due to tunneling?

\begin{tabular}{|c|c|c|c|c|c|c|c|c|}
\hline \multicolumn{9}{|c|}{ Panel A: Use related party transaction } \\
\hline & \multicolumn{4}{|c|}{ LNPATENT $_{i, t+1}$} & \multicolumn{4}{|c|}{ LNINVENT $_{i, t+1}$} \\
\hline & \multicolumn{2}{|c|}{ High RPT } & \multicolumn{2}{|c|}{ Low RPT } & \multicolumn{2}{|c|}{ High RPT } & \multicolumn{2}{|c|}{ Low RPT } \\
\hline & (1) & (2) & (3) & (4) & (5) & (6) & (7) & (8) \\
\hline PLEDGE_DUM $M_{i, t}$ & $\begin{array}{c}-0.093 * * \\
(0.042)\end{array}$ & & $\begin{array}{c}-0.097 \text { ** } \\
(0.047)\end{array}$ & & $\begin{array}{c}-0.088^{* *} \\
(0.037)\end{array}$ & & $\begin{array}{c}-0.075^{*} \\
(0.040)\end{array}$ & \\
\hline PLEDGE_RATIO ${ }_{i, t}$ & & $\begin{array}{c}-0.097 * \\
(0.056)\end{array}$ & & $\begin{array}{c}-0.185^{* * *} \\
(0.068)\end{array}$ & & $\begin{array}{c}-0.094 * * \\
(0.047)\end{array}$ & & $\begin{array}{c}-0.154^{* * *} \\
(0.057)\end{array}$ \\
\hline Control variables & Yes & Yes & Yes & Yes & Yes & Yes & Yes & Yes \\
\hline Constant & $\begin{array}{c}-8.758 * * * \\
(0.764)\end{array}$ & $\begin{array}{c}-8.764 * \\
(0.769)\end{array}$ & $\begin{array}{c}-9.861 * * * \\
(0.665)\end{array}$ & $\begin{array}{c}-9.822 * * * \\
(0.666)\end{array}$ & $\begin{array}{c}-8.495^{* * *} \\
(0.668)\end{array}$ & $\begin{array}{c}-8.498^{* * *} \\
(0.671)\end{array}$ & $\begin{array}{c}-9.331^{* * *} \\
(0.613)\end{array}$ & $\begin{array}{c}-9.297^{* * *} \\
(0.614)\end{array}$ \\
\hline$N$ & 9787 & 9787 & 9895 & 9895 & 9787 & 9787 & 9895 & 9895 \\
\hline Adjusted $R^{2}$ & 0.439 & 0.438 & 0.465 & 0.466 & 0.362 & 0.362 & 0.408 & 0.408 \\
\hline$F$ & 87.56 & 87.36 & 82.42 & 82.16 & 57.23 & 57.11 & 54.36 & 54.23 \\
\hline \multicolumn{9}{|c|}{ Panel B: Use other receivables } \\
\hline & \multicolumn{4}{|c|}{ LNPATENT $_{i, t+1}$} & \multicolumn{4}{|c|}{ LNINVENT $_{i, t+1}$} \\
\hline & \multicolumn{2}{|c|}{ High ORECTA } & \multicolumn{2}{|c|}{ Low ORECTA } & \multicolumn{2}{|c|}{ High ORECTA } & \multicolumn{2}{|c|}{ Low ORECTA } \\
\hline & (1) & (2) & (3) & (4) & (5) & (6) & (7) & (8) \\
\hline PLEDGE_DUM $M_{i, t}$ & $\begin{array}{c}-0.104^{* *} \\
(0.041)\end{array}$ & & $\begin{array}{c}-0.101^{* *} \\
(0.045)\end{array}$ & & $\begin{array}{c}-0.073^{* *} \\
(0.034)\end{array}$ & & $\begin{array}{c}-0.087^{* *} \\
(0.038)\end{array}$ & \\
\hline PLEDGE_RATIO ${ }_{i, t}$ & & $\begin{array}{c}-0.152 \text { *** } \\
(0.054)\end{array}$ & & $\begin{array}{l}-0.102 \\
(0.064)\end{array}$ & & $\begin{array}{c}-0.114 * * \\
(0.045)\end{array}$ & & $\begin{array}{c}-0.091 * \\
(0.051)\end{array}$ \\
\hline Control variables & Yes & Yes & Yes & Yes & Yes & Yes & Yes & Yes \\
\hline Constant & $\begin{array}{c}-10.068 \text { *** } \\
(0.734)\end{array}$ & $\begin{array}{c}-10.022 * * * \\
(0.737)\end{array}$ & $\begin{array}{c}-9.674^{* * *} \\
(0.687)\end{array}$ & $\begin{array}{c}-9.661 * * * \\
(0.690)\end{array}$ & $\begin{array}{c}-9.256^{* * *} \\
(0.662)\end{array}$ & $\begin{array}{c}-9.215^{* * *} \\
(0.665)\end{array}$ & $\begin{array}{c}-9.652 * * * \\
(0.642)\end{array}$ & $\begin{array}{c}-9.640 * * * \\
(0.644)\end{array}$ \\
\hline$N$ & 10,909 & 10,909 & 11,091 & 11,091 & 10,909 & 10,909 & 11,091 & 11,091 \\
\hline Adjusted $R^{2}$ & 0.468 & 0.468 & 0.444 & 0.443 & 0.401 & 0.401 & 0.387 & 0.387 \\
\hline$F$ & 87.73 & 87.42 & 84.32 & 84.25 & 59.16 & 59.01 & 52.05 & 52.03 \\
\hline
\end{tabular}




\section{Conclusions}

We examine the impact of SP on corporate innovation using a sample of Chinese firms. Our findings suggest that all else kept the same, an SP firm produces less innovation in terms of patent applications, patents granted, and research and development expenses relative to a non-SP firm. The results are robust after accounting for alternative specifications of innovation and SP, different estimation methods, and endogeneity between SP and corporate innovation. In addition, when controlling shareholders have relatively less ownership in their firms or when the stock price is volatile, the adverse impact of SP on innovation magnifies; this suggests that if the change of controlling rights is more likely to occur (due to less ownership by the controlling shareholders) or the margin call risk is higher (due to a high stock price volatility), firms engage in even fewer innovation activities. Lastly, we examine the moderating role of a firm's tunneling activities and find that whether a firm has high or low tunneling activities does not change the magnitude of the impact of SP on innovation. Thus, it is not the controlling shareholder's expropriation of minority shareholders but rather their private interest in boosting the stock price and/or minimizing a decrease in stock price that drives the adverse impact of SP on innovation. The additional results corroborate with our core findings.

The findings suggest that the unethical behavior of share-pledged controlling shareholders impedes corporate innovation. While our findings are based on a sample of Chinese firms, they also apply to other markets because of the popularity of SP in other countries, such as India (Asija et al., [1]) and Taiwan (Chan et al., [2]). The theoretical implication of our findings is that controlling shareholders with SP to behave unethically, avoid margin call risk, will direct the firms to engage in less innovation activities. Thus, in addition to the findings in the innovation literature, we document a new driver, SP, of corporate innovation.

Our findings also have policy implication given the important role of corporate innovation in promoting the sustainable development of a country and the popularity of SP worldwide. Our results suggest that the regulatory authority of a country should better review the policy of SP to avoid the possible impediment of it on the country's sustainable development.

The limitation of our paper is the endogenous problem between the variables of innovations and SP. Although we conduct several robustness tests, it is not ideal to resolve the issue due to the lack of exogenous shock on the impact of SP on innovation.

Besides the role of innovation in a country's sustainable development, innovation is also very important for a firm's long-term development. In this paper, we find that SP firms reduce innovation, but we do not know whether the reduction of innovation influences firm performance in the future. We think it is meaningful to explore this issue in the future.

Author Contributions: Conceptualization, C.O., and J.X.; methodology, X.W., and J.X.; software, X.W., and J.X.; validation, J.X.; formal analysis, C.O., X.W., and J.X.; investigation, C.O., and J.X.; resources, C.O., X.W., and J.X.; data curation, J.X. writing-original draft preparation, C.O., and J.X.; writing-review and editing, C.O., X.W., and J.X.; visualization, C.O., X.W., and J.X.; supervision, C.O.; project administration, C.O.; funding acquisition, J.X.

Funding: Jiacai Xiong acknowledge the financial support from the National Natural Science Foundation of China (Grant No. 71562015), and the Educational Commission of Jiangxi Province (Grant No. GJJ170353).

Conflicts of Interest: The authors declare no conflict of interest. 


\section{Appendix A}

Table A1. Definition of variables.

\begin{tabular}{|c|c|}
\hline Variables & Definition \\
\hline \multicolumn{2}{|l|}{ Panel A: Innovation } \\
\hline LNPATENT $_{i, t+1}$ & Natural logarithm of one plus firm $i^{\prime}$ s total number of patents filed in year $t+1$. \\
\hline$L N I N V E N T_{i, t+1}$ & $\begin{array}{l}\text { Natural logarithm of one plus firm } i \text { 's total number of invention patents filed } \\
\text { in year } t+1 \text {. }\end{array}$ \\
\hline$L N G R A N T_{i, t+1}$ & $\begin{array}{l}\text { Natural logarithm of one plus firm } i \text { 's total number of invention patents filed } \\
\text { (and eventually granted) in year } t+1 \text {. }\end{array}$ \\
\hline $\operatorname{LNIPC}_{i, t+1}$ & $\begin{array}{l}\text { Natural logarithm of one plus the number of different IPC classifications (IPC) } \\
\text { on invention patent in year } t+1 \text {. }\end{array}$ \\
\hline$R D_{i, t}$ & Research \& Development expenses/Total asset of firm $i$ in year $t$. \\
\hline \multicolumn{2}{|l|}{ Panel B: Share pledge } \\
\hline PLEDGE_DUM $M_{i, t}$ & $\begin{array}{l}\text { An indicator variable that equals one if the largest shareholder of the firm in } \\
\text { that year has made a pledge and zero otherwise of firm } i \text { in year } t \text {. }\end{array}$ \\
\hline PLEDGE_RATIO ${ }_{i, t}$ & $\begin{array}{l}\text { It equals the average number of shares pledged by the largest shareholder } \\
\text { divided by the total number of shares they hold in the company of firm } i \text { in } \\
\text { year } t \text {. }\end{array}$ \\
\hline \multicolumn{2}{|c|}{ Panel C: Mediator variables } \\
\hline$H H I 5_{i, t}$ & $\begin{array}{l}\text { Herfindahl index of shareholdings of the five largest shareholders of firm } i \text { in } \\
\text { year } t \text {. }\end{array}$ \\
\hline$S I G M A_{i, t}$ & Standard deviation of daily returns over the fiscal year of firm $i$ in year $t$. \\
\hline$R P T_{i, t}$ & Total related party transactions/Total assets of firm $i$ in year $t$. \\
\hline $\mathrm{ORECTA}_{i, t}$ & Other receivables/ Total assets of firm $i$ in year $\mathrm{t}$. \\
\hline \multicolumn{2}{|c|}{ Panel D: Control variables } \\
\hline$S I Z E_{i, t}$ & The natural logarithm of total assets of firm $i$ in year $\mathrm{t}$. \\
\hline$L E V_{i, t}^{i, t}$ & Total liabilities scaled by total assets of firm $i$ in year $t$. \\
\hline CASHFLOW $_{i, t}$ & Cash flow from operations scaled by total assets of firm $i$ in year $t$. \\
\hline$R O A_{i, t}$ & Net income/Total assets of firm $i$ in year $\mathrm{t}$. \\
\hline$A G E_{i, t}$ & The numbers of years since the firm listed of firm $i$ in year $t$. \\
\hline$P P E_{i, t}$ & Tangible assets/Total assets of firm $i$ in year $\mathrm{t}$. \\
\hline$I N V_{i, t}$ & $\begin{array}{l}\text { Cash payments for fixed assets, intangible assets, and other long-term assets } \\
\text { from the cash flow statement scaled by total assets of firm } i \text { in year } t \text {. }\end{array}$ \\
\hline$Q_{i, t}$ & $\begin{array}{l}\text { The sum of market value of tradable shares, book value of non-tradable } \\
\text { shares, and liabilities, scaled by book value of total assets of firm } i \text { in year } t \text {. }\end{array}$ \\
\hline $\mathrm{TOP} 1_{i, t}$ & The percentage shareholdings of the largest shareholder of firm $i$ in year $t$. \\
\hline
\end{tabular}

\section{References}

1. Asija, A.; Marisetty, V.B.; Rangan, S. Do insiders Who Pledge Their Shares Manipulate Reported Earnings? Asia MIT Conference Working Paper 2016. Available online: https://www.nseindia.com/research/content/ 1314_BS3.pdf (accessed on 9 May 2019).

2. Xie, D.; Liao, K. Share pledging by controlling shareholders and real earnings management of listed firms. China J. Account. Stud. 2018, 6, 109-119. [CrossRef]

3. Chan, K.; Chen, H.K.; Hu, S.Y.; Liu, Y. Share pledges and margin call pressure. J. Corp. Financ. 2018, 52, 96-117. [CrossRef]

4. Ouyang, C.; Xiong, J.; Fan, L. Do insiders share pledging affect executive pay-for-performance sensitivity? Int. Rev. Econ. Financ. 2019. [CrossRef]

5. OECD; Eurostat. Oslo Manual: Guidelines for Collecting and Interpreting Innovation Data, 4th ed.; OECD Publishing: Paris, France, 2018. [CrossRef]

6. Balsmeier, B.; Fleming, L.; Manso, G. Independent Boards and Innovation. Journal of Financial Economics 2017, 123, 536-557. [CrossRef]

7. Holmstrom, B. Agency costs and innovation. J. Econ. Behav. Organ. 1989, 12, 305-327. [CrossRef] 
8. Choi, J.Y.; Han, D.B. The Links between Environmental Innovation and Environmental Performance: Evidence for High- and Middle-Income Countries. Sustainability 2018, 10, 2157. [CrossRef]

9. Krozer, Y.; Nentjes, A. An essay on innovations for sustainable development. Environ. Sci. 2006, 3, $163-174$. [CrossRef]

10. Silvestre, B.S.; Tirca, D.M. Innovations for sustainable development: Moving toward a sustainable future. J. Clean. Prod. 2019, 28, 325-332. [CrossRef]

11. Fisher Vanden, K.; Jefferson, G.H.; Ma, J.; Xu, J. Technology development and energy productivity in China. Energy Econ. 2006, 28, 690-705. [CrossRef]

12. Jin, L.; Duan, K.; Tang, X. What Is the Relationship between Technological Innovation and Energy Consumption? Empirical Analysis Based on Provincial Panel Data from China. Sustainability 2018, 10, 145. [CrossRef]

13. Tang, C.F.; Tan, E.C. Exploring the nexus of electricity consumption, economic growth, energy prices and technology innovation in Malaysia. Appl. Energy 2013, 104, 297-305. [CrossRef]

14. Griffin, P. The Carbon Majors Database: CDP Carbon Majors Report 2017. CDP Report 2017. Available online: https://www.cdp.net/en/articles/media/new-report-shows-just-100-companies-are-source-of-over70-of-emissions (accessed on 9 May 2019).

15. Baumol, W.J. The Free-Market Innovation Machine: Analyzing the Growth Miracle of Capitalism; Princeton University Press: Princeton, NJ, USA, 2001.

16. Cumming, D.; Rui, O.; Wu, Y. Political instability, access to private debt, and innovation investment in China. Emerg. Mark. Rev. 2016, 29, 68-81. [CrossRef]

17. Hwang, A.L.; Qiao, Y.; Qiao, K.C. Pledge or not pledge? Shares owned by insiders pledged for collateral. Int. J. Manag. Theory Pract. 2016, 17, 36-54.

18. Riivari, E.; Lämsä, A.M. Does it pay to be ethical? Examining the relationship between organisations' ethical culture and innovativeness. J. Bus. Ethics 2014, 124, 1-17. [CrossRef]

19. Chen, A.; Kao, L. Effect of collateral characteristics on bank performance: Evidence from collateralized stocks in Taiwan. J. Bank. Financ. 2011, 35, 300-309. [CrossRef]

20. Dou, Y.; Masulis, R.W.; Zein, J. Shareholder Wealth Consequence of Insider Pledging of Company Stock as Collateral for Personal Loans; SSRN Working Paper; SSRN: Rochester, NY, USA, 2016. [CrossRef]

21. Wang, Y.; Chou, R.K. The impact of share pledging regulations on stock trading and firm valuation. J. Bank. Financ. 2018, 89, 1-13. [CrossRef]

22. Ouyang, C.; Wang, X.; Chan, K.C. Do Insiders' Share Pledges Affect Bond Yield Spreads? Evidence from an Emerging Market; SSRN Working Paper; SSRN: Rochester, NY, USA, 2018. [CrossRef]

23. Brown, J.R.; Martinsson, G.; Petersen, B.C. Law, stock markets, and innovation. J. Financ. 2013, 68, 1517-1549. [CrossRef]

24. Fang, L.H.; Lerner, J.; Wu, C. Intellectual property rights protection, ownership, and innovation: Evidence from China. Rev. Financ. Stud. 2017, 30, 2446-2477. [CrossRef]

25. Aghion, P.; Bloom, N.; Blundell, R.; Griffith, R.; Howitt, R. Competition and innovation: An inverted-U relationship. Q. J. Econ. 2005, 120, 701-728. [CrossRef]

26. He, J.; Tian, X. The dark side of analyst coverage: The case of innovation. J. Financ. Econ. 2013, 109, 856-878. [CrossRef]

27. Jiang, X.; Yuan, Q. Institutional investors' corporate site visits and corporate innovation. J. Corp. Financ. 2018, 48, 148-168. [CrossRef]

28. Guo, R.; Zhou, N. Innovation capability and post-IPO performance. Rev. Quant. Financ. Account. 2016, 46, 335-357. [CrossRef]

29. Chan, L.K.C.; Lakonishok, J.; Sougiannis, T. The stock market valuation of research and development expenditures. J. Financ. 2001, 56, 2431-2456. [CrossRef]

30. Eberhart, A.C.; Maxwell, W.F.; Siddique, A.R. An examination of long-term abnormal stock returns and operating performance following R\&D increases. J. Financ. 2004, 59, 623-650. [CrossRef]

31. Zhou, M.; Xiao, D.; Chan, K.; Fung, H. The impact of pre-IPO performance pressure on research and development investments of an IPO firm: Evidence from China. Econ. Model. 2019. [CrossRef]

32. Zang, Z.; Zhu, Q.; Mogorron-Guerrero, H. How does R\&D investment affect the financial performance of cultural and creative enterprises? The moderating effect of actual controller. Sustainability 2019, 11, 297. [CrossRef] 
33. Tong, T.; He, W.; He, Z. Intellectual Property Regime Shift and Firms' Patenting Strategy. Working Paper, University of Colorado. 2015. Available online: https://sites.insead.edu/facultyresearch/research/file.cfm? fid=57904 (accessed on 9 May 2019).

34. Atanassov, J. Do hostile takeovers stifle innovation? Evidence from antitakeover legislation and corporate patenting. J. Financ. 2013, 68, 1097-1131. [CrossRef]

35. Hall, B.H.; Ziedonis, R.H. The patent paradox revisited: An empirical study of patenting in the US semiconductor industry, 1979-1995. Rand J. Econ. 2001, 32, 101-128. [CrossRef]

36. Tu, G.; Lin, B.; Liu, F. Political connections and privatization: Evidence from China. J. Account. Public Policy 2013, 32, 114-135. [CrossRef]

37. Jiang, G.; Lee, C.M.C.; Yue, H. Tunneling through intercorporate loans: The China experience. J. Financ. Econ. 2010, 98, 1-20. [CrossRef]

38. Wang, K.; Xiao, X. Controlling shareholder's tunneling and executive compensation: Evidence from China. J. Account. Public Policy 2011, 30, 89-110. [CrossRef]

(C) 2019 by the authors. Licensee MDPI, Basel, Switzerland. This article is an open access article distributed under the terms and conditions of the Creative Commons Attribution (CC BY) license (http://creativecommons.org/licenses/by/4.0/). 